\title{
Population structure of Uncancylus concentricus (d'Orbigny, 1835) (Ancylidae, Pulmonata, Basommatophora) in the Multiple Use Reserve Martín García Island, Upper Río de la Plata, Argentina
}

\author{
Martín, SM.* and Díaz, AC. \\ anvestigador Adjunto S/D CIC, División Zoología Invertebrados, \\ Facultad de Ciencias Naturales y Museo La Plata, Paseo del Bosque S/N., La Plata (1900), Buenos Aires. \\ *e-mail: smartin@fcnym.unlp.edu.ar
}

Received November 25, 2011 - Accepted February 22, 2011 - Distributed February 29, 2012

(With 3 figures)

\begin{abstract}
The present work analyzes the population dynamics of Uncancylus concentricus in natural conditions in the northeastern coastal area of the Multiple Use Natural Reserve Isla Martín García (Beach of Basural), Buenos Aires, Argentina. Martín García Island is located in the Upper Río de La Plata, to the south of the mouth of the Uruguay River (34 11' $25^{\prime}$ " S and $58^{\circ} 15^{\prime} 38^{\prime \prime}$ W). Monthly collections were made from August 2005 to December 2006. The size frequency of the $U$. concentricus population throughout the sampling period ranges from 1.2 to $8.3 \mathrm{~m}$. The changes in the size frequencies throughout the months surveyed indicate a variable distribution pattern because of the increase and decrease in water flow, but we observed a peak in the frequency of individuals within the size range 3.5 to $4.5 \mathrm{~mm}$ in the population. It can be concluded that this species lives for at least a year in the wild since the juveniles are highly abundant in spring and summer.
\end{abstract}

Keywords: Uncancylus concentricus, population dynamics, Martin García Island, Argentina.

\section{Estrutura populacional de Uncancylus concentricus (d'Orbigny, 1835) (Ancylidae, Pulmonata, Basommatophora) da Reserva Natural de Usos Múltiplos Ilha Martín García no Rio de La Plata Superior, Argentina}

\begin{abstract}
Resumo
O presente trabalho analisa a dinâmica populacional de Uncancylus concentricus em condições naturais da zona costeira noroeste da Reserva Natural de Usos Múltiplos Ilha Martín García (Praia de Basural), Buenos Aires, Argentina. A Ilha Martín García está localizada no Rio da Prata Superior, ao sul da desembocadura do Rio Uruguai $\left(34^{\circ} 11^{\prime}\right.$ ' 25" S e $58^{\circ} 15^{\prime} 38^{\prime \prime} \mathrm{W}$ ). Amostras mensais foram analisadas entre os meses de agosto de 2005 e dezembro de 2006 . Foi determinado que a população de $U$. concentricus ao longo do período de amostragem tem uma frequência de comprimento que varia de 1,2 a $8,3 \mathrm{~mm}$. As mudanças nas frequências de tamanho ao longo dos meses pesquisados indicam um padrão de distribuição variável, devido ao aumento e à diminuição do fluxo de água; entretanto, observou-se um pico na frequência de indivíduos na faixa de tamanho de 3,5 a 4,5 mm na população. Conclui-se que essa espécie vive há pelo menos um ano em condições naturais e os juvenis são muito abundantes na primavera e no verão.
\end{abstract}

Palavras-chave: Uncancylus concentricus, estrutura populacional, Ilha Martín García, Argentina.

\section{Introduction}

Uncancylus concentricus (d'Orbigny, 1835) belongs to the Ancylidae family and is distributed throughout the Neotropical region from Costa Rica to Lago Buenos Aires, Patagonia, Argentina.(Dos Santos, 2003). U. concentricus has likewise been registered in Ecuador and Peru (Lanzer, 1996), Venezuela (Hubendick, 1967), and Brazil (Haas, 1949a, 1949b, 1952; Irmler, 1975). This species was first noted and characterized in Antioquía (Colombia) by Gomez et al. (2004).
The species of this family inhabit lotic and lentic environments of inland limnic ecosystems worldwide. Within the Neotropical region, the Ancylidae are represented by seven genera, Anisancylus Pilsbry, 1924; Gundlachia Pfeiffer, 1849; Uncancylus Pilsbry, 1913; Hebetancylus Pilsbry, 1913; Burnupia Walker, 1912; Ferrissia, Walker, 1903; and Laevapex Walker, 1903 (Lanzer, 1991, 1996; Dos Santos, 2003). According to Walther (2008), the genera from the new world (Laevapex, Hebetancylus, Uncancylus, 
Gundlachia) are members of a Holartic clade, which also includes the following genera: Ferrissia and Ancylus Müller, 1774. The Ancylidae play a key role in ecosystems both as the prey of invertebrates, fish, aquatic birds and as grazing predators of algae, thus affecting the population development of other predatory organisms.

Ecological studies on gastropods of medicinal and veterinary relevance have gained great significance because of the role that certain species within the community can play as either competitors or predators regulating the populations of disease-transmitting organisms (Ferrer Junior et al. 1989).

Snails are medically significant gastropods also as a result of their ability to act as temporary hosts for trematodes (Platyhelmintes). In India, Ferrissia tenuis (Bourguignat, 1862) by Gadgil and Shah (1955) has been identified as the intermediate host for Schistosoma haematobium (Basch, 1963; Morgan et al., 2002; Thiengo et al., 2004). Moreover, Thiengo et al. (2000) reported the presence of larvae of the nematode family Anisakidae in the visceral cavity of specimens of Gundlachia radiata (Guilding, 1828) within the area of Pantanal de Paiagua's, Mato Grosso do Sul, Brazil.

In addition to these medically related associations, certain species, such as Burnupia stenochorias (Melvill and Ponsonby, 1903), have been reported as potential indicators of toxicity within the Eastern Cape of South Africa (Davies-Coleman and Palmer, 2004).

Despite the importance of these freshwater gastropods in terms of ecology and medicine, the Ancylidae family has been poorly studied over the last decades, while the few investigations conducted along those lines have thus far been complicated by persistent systematic uncertainties (Jørgensen et al., 2004; McMahon, 2004).

The freshwater gastropods from Martín García Island include species from the families Ampullariidae, Hydrobiidae, Physidae, Chilinidae, Planorbidae, and Ancylidae. The last of these is represented by the genera Uncancylus Pilsbry, 1913 and Hebetancylus Pilsbry, 1913.

The aim of this work was to analyze the population structure of $U$. concentricus in natural conditions in the northeastern coastal area (Basural Beach) of the Multiple Use Natural Reserve Martín García Island, in the upper Río de La Plata estuary, Argentina. Various thorough investigations on the biodiversity of the fauna and flora of this island have already been conducted at the Reserve (Lahitte and Hurrell, 1988, 1994; Rumi et al., 1996; Armendariz et al., 2000; Armendariz and César, 2001; César et al., 2009; Martin et al., 2009) and this constitutes a ready source of background information.

\section{Material and Methods}

\subsection{Study site}

Martín García Island is located in the upper Rio de la Plata estuary south of the mouth of the Uruguay river $\left(34^{\circ} 11^{\prime} 25^{\prime \prime} \mathrm{S}\right.$ and $58^{\circ} 15^{\prime} 38^{\prime \prime} \mathrm{W}$ ) (Figure 1). It constitutes an outcrop of the Brazilian massif of Precambrian crystalline basement rocks, upon which there are sediments of the Holocene and Pleistocene (Quaternary) (Ravizza, 1984). The climate of the island is temperate and humid with a mean annual temperature of $17.6^{\circ} \mathrm{C}$ and an annual precipitation of $980 \mathrm{~mm}$.

The site sampled in the present study is the Basural Beach located on the northeastern coast of the island. The area contains abundant communities of coastal plants commonly known as rushes. The area is delimited by the coastal strip of the marginal forest inland and by rushes toward the coast. These latter grasslands include species of Echinodorus grandiflorus, Eryngium pandanifolium, Schoenoplectus californicus, and the cortaderal Cortadera selloana (Lahitte and Hurrell, 1996; Lahitte et al., 1997).

\subsection{Methods}

Monthly collections of $U$. concentricus were conducted from August 2005 to December 2006. Specimens $(n=620)$ were collected by hand in the coastal area (captures per unit effort: CPUE, that is, specimens/60 minutes/person). The environmental physico-chemical parameters such as water and air temperature, dissolved oxygen (mg.L $\left.\mathrm{L}^{-1}\right)$, dissolved solids (TDS) and $\mathrm{pH}$ were measured. All variables were measured using a digital Water Quality Meter (Sper Scientific Ltd). The correlation coefficient between environmental variables and the modal lengths to estimate the degree of association were calculated (Table 1)

In the field, using brushes, the specimens were separated and extracted from the angle formed by the stem and leaves of the aquatic vegetation and from the decomposed leaves. The snails thus collected were kept alive for transportation to the laboratory in plastic containers with water from the site. There, we followed the techniques of fixation and dissection suggested by Thiengo (1995).

The total length of the specimens was selected as the parameter to determine the size frequency of the population studied. We measured the specimen's body length under a stereoscopic microscope equipped with a micrometer in the ocular (Dos Santos, 2003). The size frequencies obtained were used to graph the seasonal population structure.

\section{Results}

Size distribution: The size frequency of the $U$. concentricus population ranged from 1.2 to $8.3 \mathrm{~mm}$ throughout the sampling period.

The juveniles ( 1 to $2 \mathrm{~mm}$ ) appeared in the spring and summer, but thereafter became incorporated in the population throughout the year. Individuals whose sizes ranged from 3.5 to $4.5 \mathrm{~mm}$ (mature adults) were recorded from September to November along with senile specimens (4,5 to $8,2 \mathrm{~mm})$ during the same period.

It can be inferred that this species lives for at least a year in the wild since the juveniles are highly abundant in spring and summer. The changes in the size frequencies throughout the months surveyed indicate a variable distribution pattern because of the increase and decrease in water flow, but we observed a peak in the frequency 


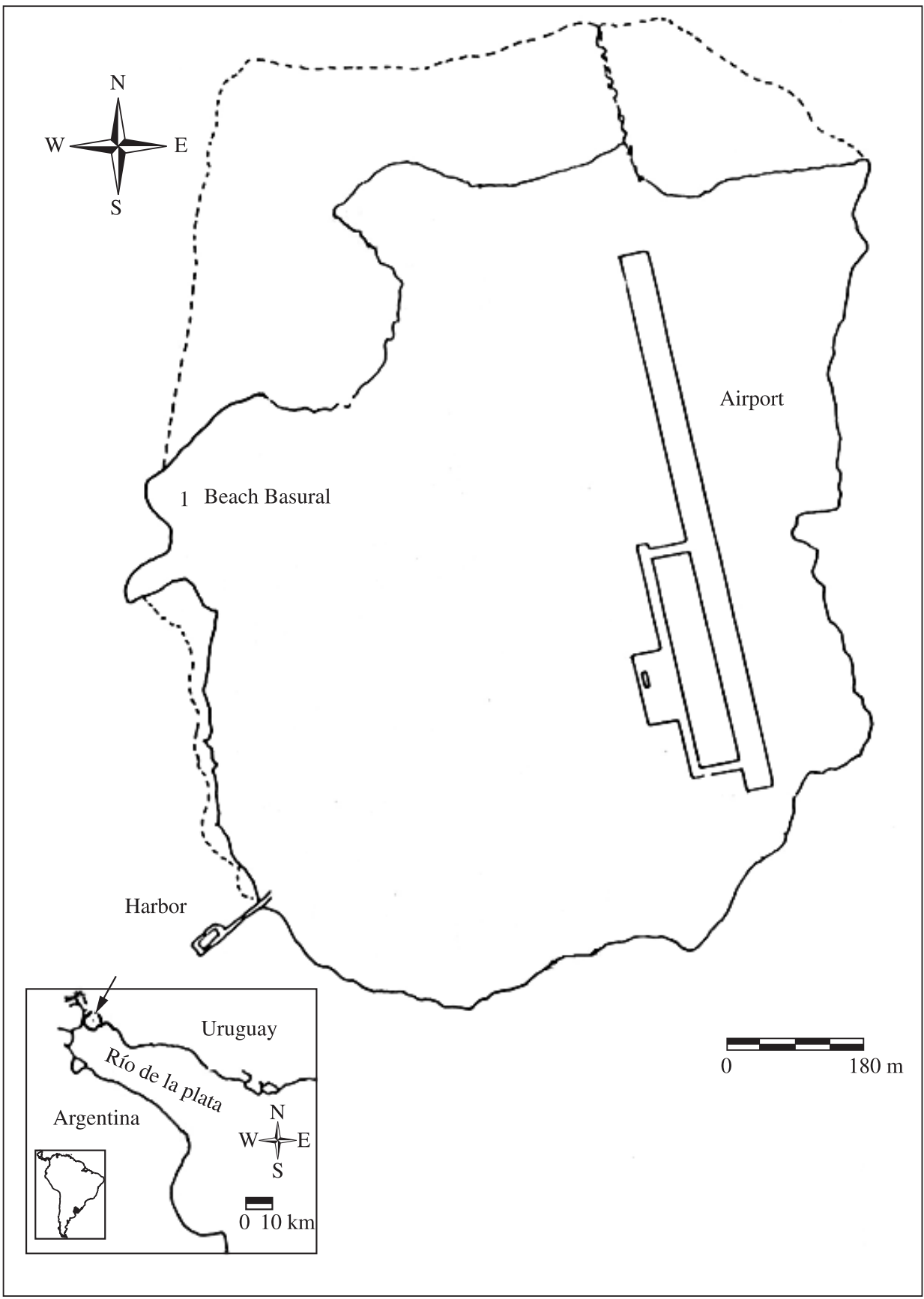

Figure 1. Martín Garcia Island map with station Basural Beach.

Table 1. Mean, range and correlation coefficient of the environmental variables.

\begin{tabular}{lccc}
\hline Environmental variables & Mean & Range & Correlation coefficient (r) \\
\hline TDS $(\mathrm{g})$ & 97 & $1.2-307$ & 0.43 \\
Water temperature $\left({ }^{\circ} \mathrm{C}\right)$ & 23 & $16.1-32$ & 0.63 \\
$\mathrm{O}_{2}\left(\mathrm{mg}^{\mathrm{L}} \mathrm{L}^{-1}\right)$ & 5.25 & $0.7-8.01$ & 0.18 \\
$\mathrm{pH}$ & 7.55 & $6.38-8.62$ & 0.55 \\
\hline
\end{tabular}


of individuals within the size range 3.5 to $4.5 \mathrm{~mm}$ in the population. The water temperature during this period ranges from 17.8 to $32.0^{\circ} \mathrm{C}$. New recruitments were not observed during autumn and winter; this population only consists of adults, but contains a low frequency of seniles (Figure 2).

Environmental Variables: The analysis of environmental variables in Basural Beach throughout the sampling period from August 2005 to December 2006 indicated high average
$\mathrm{pH}$ values, most likely related to the low water levels (low tides). In general, however, the dissolved oxygen and conductivity of the water remained at moderate mean values. The correlation coefficients of water temperature, dissolved oxygen, $\mathrm{pH}$ and dissolved solids with the modal lengths of $U$. concentricus population were calculated. Figure 3 shows the changes in water temperature, dissolved oxygen and pH between August 2005 to December 2005.

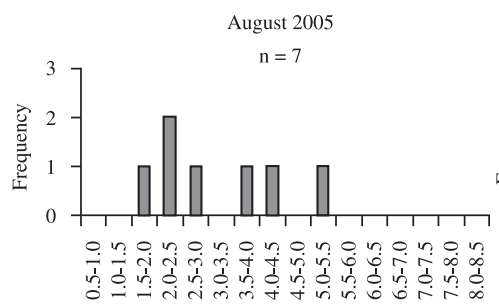

Lenght (mm)

November 2005

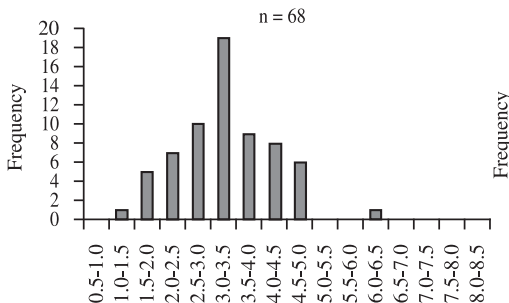

Lenght (mm)

March 2006

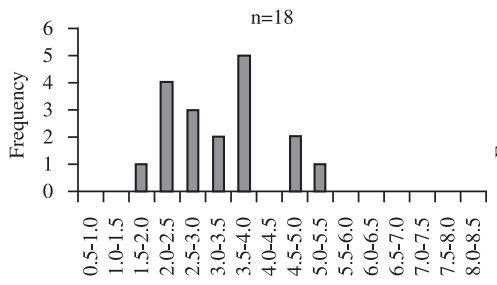

Lenght (mm)

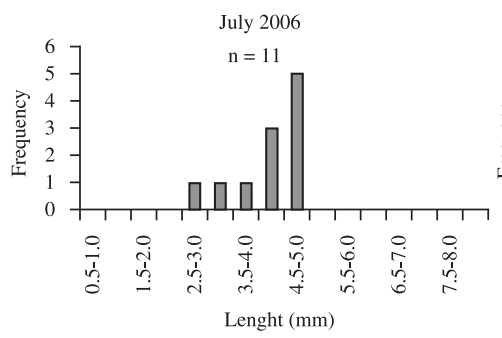

Lenght (mm)

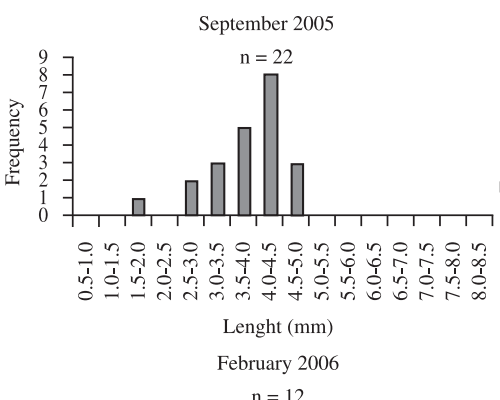

$\mathrm{n}=12$

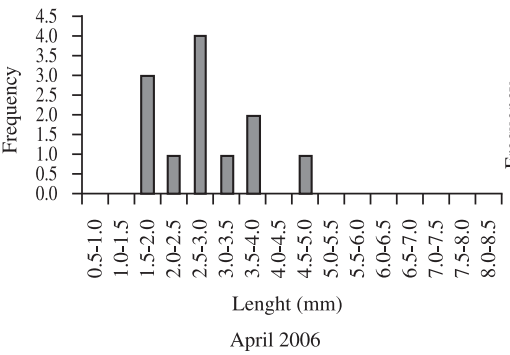

$\mathrm{n}=19$

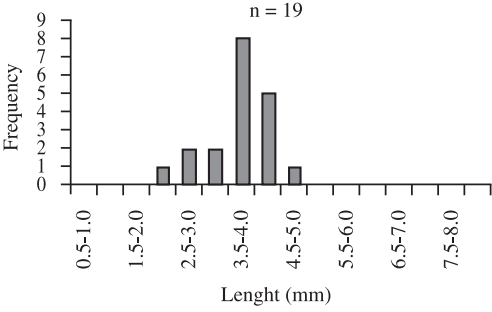

August 2006

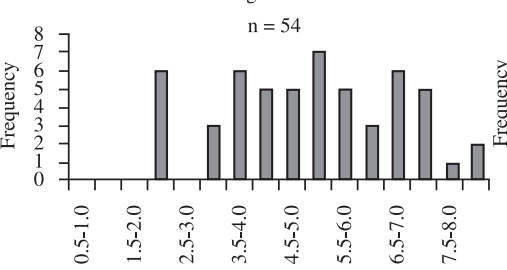

Lenght (mm)

November 2006

$\mathrm{n}=143$

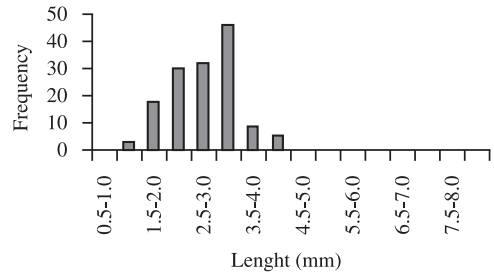

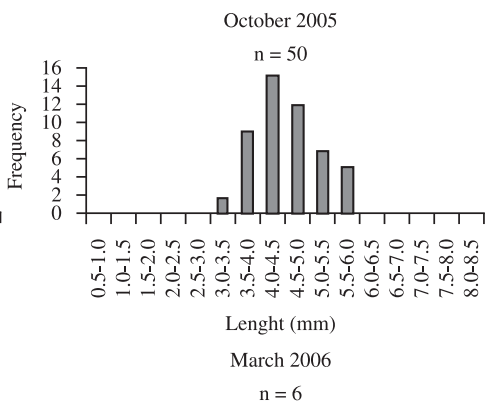
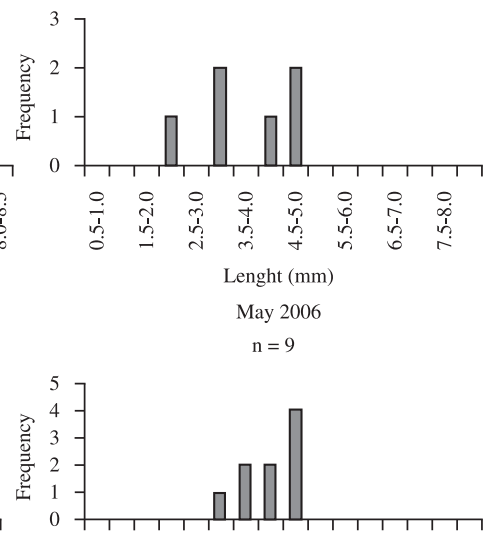

ڤั่

Lenght (mm)

September 2006

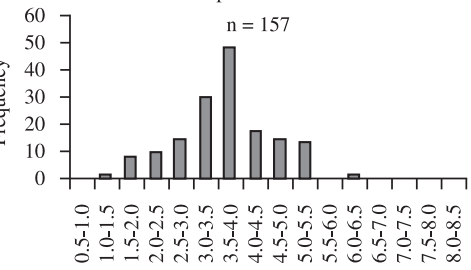

Lenght (mm)

December 2006 $\mathrm{n}=94$

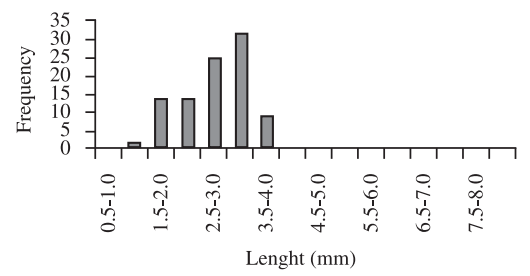

Figure 2. Size frequency distributions of Uncancylus concentricus in Basural Beach, Martin Garcia Island. 


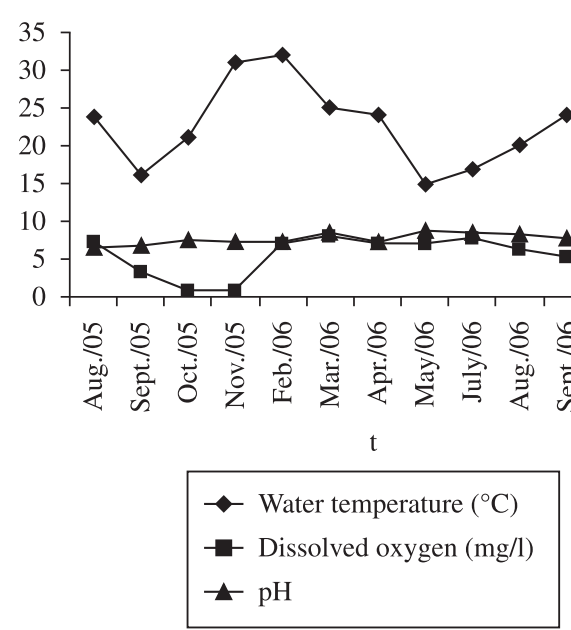

Figure 3. Distribution of temperature, dissolved oxygen and pH in "Basural Beach", Martín Garcia Island.

\section{Discussion}

The present study followed and recorded the seasonal timing and life-cycle of populations of $U$. concentricus along with their ability to adapt to the range of climatic and ecological variations in the Multiple Use Natural Reserve Martín García Island. The occurrence of the highest abundance of juveniles during the spring and summer indicated that the population structure of this species is most affected by the environmental variable of water temperature. The longevity of this species may not exceed a year in the wild, with those same two seasons being the period of maximum number of individuals present. The temperature could be a regulating influence on growth and reproductive activity, although this and related questions must await future studies on gametogenesis and body sizes for complete confirmation.

A comparison of the size frequency of $U$. concentricus within Basural Beach with that of populations from other Ancylidae genera elsewhere such as Ancylus fluviatilis Müller, 1774 from Europe, as reported by Geldiay (1956), Durrant (1980), and McMahon (2004) revealed that despite the differences in the latitudes of their habitats, the size frequencies of these species are determined by the ambient water temperature, and their growth rate is the same as one generation per year. Hunter $(1953,1961)$, and McMahon (1976) described these types of life cycles in detail.

Uncancylus concentricus likewise showed a similarity to Ferrisia wautieri (Mirolli, 1960), another European species (The Netherlands), in that the occurrence of juveniles within the size frequency throughout the year mainly depended on the water temperature as well (Hadderingh et al., 1987; Van Der Velde, 1991) (correlation coefficient $r=0,63$ ). According to Durrant (1980) these results would indicate that, with population-growth kinetics such as these, a long period of study is required to observe a reproducible pattern.
With regards to the influence of the measured environmental variables, we can infer that the constant values total levels of dissolved solids (correlation coefficient $r=0,43$ ), dissolved-oxygen concentrations (correlation coefficient $\mathrm{r}=0,18$ ), and $\mathrm{pH}$ (correlation coefficient $r=0,55$ ) occurring within the eastern coastal area (Basural Beach) affect the size frequencies of $U$. concentricus throughout the year.

Finally, it can be inferred that the longevity of this species does not exceed the year in natural conditions and is very abundant in spring and summer, mostly showing the presence of numerous juveniles.

Acknowledgements - Financial support for this work was provided by an institutional grant from the Comisión de Investigaciones Científicas de la Provincia de Buenos Aires (CIC) (Resolution $\mathrm{n}^{\circ}$ 578/08) and Facultad de Ciencias Naturales y Museo, Universidad Nacional de La Plata (Proyect 11/N470). The authors wish to thank Mr. José David Maciel of Martín García Island for his cooperation and assistance and are grateful to Dr. Donald F. Haggerty, a retired career investigator and native English speaker, for editing the final version of the manuscript.

\section{References}

ARMENDARIZ, LC. and CESAR, II., 2001. The distribution and ecology of littoral Oligochaeta and Aphaoneura (Annelidae) of the Natural and Historical reserve of Isla Martín García, Río de la Plata River, Argentina. Hydrobiologia, vol. 463, p. 207-216.

ARMENDARIZ, LC., CESAR, II. and DAMBORENEA, MC., 2000. Oligoquetos en ambientes lénticos de La Reserva Natural e Histórica de la Isla Martín García, Río de la Plata Superior, Argentina. Natura Neotropicalis, vol. 31, no. 1-2, p. 73-79.

BASCH, PF., 1963. A review of the recent freshwater limpet snails of North America (Mollusca:Pulmonta). Bulletin of the Museum of Comparative Zoology, vol. 129, p. 399-461.

CÉSAR, II., MARTÍN, SM., GULLO, BS. and LIBERTO, R., 2009. Biodiversity and ecology of Hirudinea (Annelida) from the Natural Reserve of Isla Martín García, Río de la Plata, Argentina. Brazilian Journal of Biology, vol. 69, n 4, p. 1107-1113.

DAVIES-COLEMAN, HD. and PALMER, CG., 2004. The use of a freshwater mollusc, Burnupia stenochorias (Ancylidae) as an ecotoxicological indicator in whole effluent toxicity testing. Proceedings of the 2004 Water Institute of Southern Africa (WISA) Biennial Conference Cape Town, 2004. South Africa. p. 309-315.

DOS SANTOS, SB., 2003. Estado atual do conhecimento dos ancilídeos na América do Sul (Mollusca: Gastropoda: Pulmonata: Basommatophora). Revista de Biología Tropical, vol. 51, suppl. 3, p. 191-224.

DURRANT, PM., 1980. The growth of a population of Ancylus fluviatilis Müller, from the R.Lea, Hertford. Journal Molluscan Studies, vol. 46, p. 257-264.

FERRER JUNIOR, L., PERERA, G., YONG, M. and AMADOR, O., 1989. Estudio de densidad de hospederos intermediarios de enfermedades tropicales en berreras. Revista Cubana Medicina Tropical, vol. 41, n. 3, p. 341-354.

GADGIL, RI. and SHAH, SN., 1955. Human schistosorniasis in India. Part 11. Infection of snails with $S$. haematobium. Indian Journal of Medicine Research, vol. 43, p. 695-701. 
GELDIAY, R., 1956. Studies on local populations of the freshwater limpet Ancylus fluviatilis Müller. Journal of Animal Ecology, vol. 25, n. 2, p. 389-402. http://dx.doi.org/10.2307/1933

GOMEZ, MI., BARBOSA DOS SANTOS, S. and ROLDAN, G., 2004. Ancylidae from the Department of Antioquía, Colombia, with new records (Pulmonata, Basommatophora). Caldasia, vol. 26, no. 2, p. 439- 443.

HAAS, F., 1949a. Land und Süsswssermollusken aus dem Amazonas-Gebiete. Archive für Molluskenkunde, vol. 78, n. 4-6, p. $149-156$.

-, 1949b. On fresh water Mollusks from the Amazonian region. Anales Instituto Biología Mexicana, vol. 20, p. 301-314.

-, 1952. South American non-marine shells: further remarks and description. Fieldiana Zoology, vol . 34, n. 9, p. 107-132.

HADDERINGH, RH., VAN DER VELDE, G. and SCHNABEL, PG., 1987. The effect of heated effluent on the occurrence and reproduction of the freshwater limpets Ancylus fluviatilis Müller, 1774, Ferrisia wautieri (Mirolli, 1960) and Acroloxus lacustris (Lamarck, 1758) in two dutch water bodies. Hydrobiological Bulletin, vol. 21, no. 2, p. 193-205. http://dx.doi.org/10.1007/ BF02255445

HUBENDICK, B., 1967. Studies on Ancylidae. The Australian, Pacific and Neotropical formgroups. Göteborgs Kungl. Vetenskapsoch Vitterhets-Samhälles Handlingar (Zoology), vol. 1, p. 1-52.

HUNTER, RW., 1953. On the growth of the freshwater limpet Ancylus fluviatilis Müller. Proceedings of the Zoological Society London, vol. 123, p. 623-636.

-, 1961. Annual variations in growth and density in natural populations of freshwater snails in the West of Scotland. Proceedings of the Zoological Society London, vol. 136, p. 219-253.

IRMLER, U., 1975. Ecological studies of aquatic soil invertebrates in three inundation forests of Central-Amazonia. Amazoniana, vol. 5 , p. $337-409$.

JØRGENSEN, A., KRISTENSEN, TK. and STOTHARD, JR., 2004. An investigation of the "Ancyloplanorbidae" (Gastropoda, Pulmonata, Hygrophila): preliminary evidence from DNA sequence data. Molecular Phylogenetic Evolution, vol. 32, p. 778-787. PMid:15288055. http://dx.doi.org/10.1016/j.ympev.2004.02.011

LAHITTE, HB. and HURREL, J., 1988. Catálogo de las aves de la Isla Martín García (Bs. As., Argentina). Buenos Aires. 69 p. Serie Informes CIC, no. 53.

-, 1994. Flora arbórea y arborescente de la Isla Martín García. Buenos Aires. 230 p. Serie Informes CIC, no. 47.

-, 1996. Plantas hidrófilas de la Isla Martín García (Buenos Aires, República Argentina). Buenos Aires. p. 1-236. Serie Informes CIC, no. 52

LAHITTE, HB., HURREL, J., BELGRANO, MJ., JANKOWSKI, LS., MEHLTRETER, K., HALOUA, MP. and CANDA, G., 1997. Plantas de la costa. Buenos Aires: Edición L.O.L.A. 200 p.

LANZER, R., 1991. Duas novas espécies de Ancylidae (Gastropoda: Basommatophora) para o sul do Brasil. Revista Brasileira de Biologia, vol. 51, no. 4, p. 703-719.
-, 1996. Ancylidae (Gastropoda, Basommatophora) na América do Sul: Sistemática e Distribução. Revista Brasileira.de Zoología, vol. 13, no. 1, p. 175-210.

McMAHON, RF., 1976. Growth, reproduction and life cycle in six Texan populations of two species of freshwater limpets. The American Midland Naturalist, vol. 95, p. 174-185.

-, 2004. A 15-year study of interannual shell-shape variation in a population of freshwater limpets (Pulmonata: Basommatophora: Ancylidae). American Malacologica! Bulletin, vol. 19, p. 101-109.

MARTIN, SM., CESAR, II. and LIBERTO, R., 2009. Distribution of Deroceras reticulatum (Müller, 1774) (Pulmonata Stylommatophora) in Argentina with first record of the Reserva de Usos Múltiples Isla Martin Garcia, Río de la Plata superior. Brazilian Journal of Biology, vol. 69, n. 4, p. 1115-1119.

MORGAN, JAT., DEJONG, RJ., JUNG, Y., KHALLAAYOUNE, K., KOCK, S., MKOJI, GM. and LOKER, ES., 2002. A phylogeny of planorbid snails, with implications for the evolution of Schistosoma parasites. Molecular Phylogenetic Evolution, vol. 25, p. 477- 488. http://dx.doi.org/10.1016/S1055-7903(02)00280-4

RAVIZZA, GB., 1984. Principales aspectos geológicos del Cuaternario en la Isla Martín García, Río de la Plata Superior. Revista de la Asociación Geológica Argentina, vol. 39, p. 125-130.

RUMI, A., MARTÍN, SM., TASSARA, MP. and DARRIGRAN, GA., 1996. Moluscos de agua dulce de la Reserva Natural e Histórica Isla Martín García, Río de La Plata, Argentina. Comunicaciones de la Sociedad Malacológica del Uruguay, vol. 8, no. 70-71, p. 7-12.

THIENGO, SC., 1995. Técnicas malacológicas en Tópicos. In BARBOSA, FS. (Ed.). Tópicos em Malacologia Médica. Rio de Janeiro: Editora Fiocruz. p. 255-265.

THIENGO, SC., MATTOS, AC., BOAVENTURA, MF., LOUREIRO, MS., SANTOS, SB. and FERNANDEZ, MA., 2004. Freshwater Snails and Schistosomiasis Mansoni in the State of Rio deJaneiro, Brazil: V Norte Fluminense Mesoregion. Memórias do Instituto Oswaldo Cruz, vol. 99, p. 99-103. http://dx.doi. org/10.1590/S0074-02762004000900018

THIENGO, SC., SANTOS, SB., VICENTE, JJ. and PINTO, RM., 2000. Occurrence of Contracaecum sp. Larvae (Nematoda, Anisakidae) in Gundlachia radiata (Guilding, 1828) (Mollusca, Gastropoda, Ancylidae) in Brazil. Journal of Invertebrate Pathology, vol. 75, no. 2, p. 178-179. PMid:10772332. http:// dx.doi.org/10.1006/jipa.1999.4912

Van DEL VELDE, G., 1991. Population dynamics and population structure of Ferrisia wauteri (Mirolli, 1960) (Gastropoda, Ancylidae) in a pond near Nijmegen (The Netherlands). Bulletin Hydrobiología, vol. 24, no. 2, p. 141-144.

WALTHER, A., 2008. A Systematic Study of North American Freshwater limpets (Gastropoda: Hygrophila: Ancylidae). University of Michigan. p. 112. Dissertation Doctoral Ecology and Evolutionary Biology. 